\title{
PERLINDUNGAN HUKUM BAGI PIHAK PENJUAL TERHADAP PIHAK PEMBELI WANPRESTASI DALAM IKATAN JUAL BELI TANAH
}

\author{
Oleh \\ Bambang Eko Muljono \\ ${ }^{2}$ Dosen Fakultas Hukum Universitas Islam Lamongan
}

\begin{abstract}
ABSTRAK
Dalam suatu perjanjian pada umumnya salah satu asas yang dikenal adalah asas kebebasan berkontrak yang memberikan kebebasan kepada para pihak untuk menentukan sendiri hal-hal yang disepakati dalam perjanjian, namun tetap tidak bertentangan dengan kepentingan umum dan norma-norma yang berlaku. Dalam perjanjian jual beli tanah tersebut didasarkan pada suatu perjanjian dimana untuk sahnya suatu perjanjian berdasarkan Pasal 1320 KUHPerdata mengandung empat syarat yaitu:

1. Sepakat mereka yang mengikatkan dirinya

2. Kecakapan untuk membuat suatu perikatan

3. Suatu hal tertentu

4. Suatu sebab yang halal

Perjanjian Pengikat Jual Beli adalah akta otentik yang dibuat di hadapan Notaris. Teori kontrak yang modern cenderung untuk menghapuskan syarat-syarat formal bagi kepastian hukum (Jack Beatson dan Daniel Friedman) sehingga perlu adanya pengaturan hukum yang tegas dalam menangani hal ini.

Perlindungan hukum yang diberikan kepada pihak penjual ketika pihak pembeli wanprestasi dalam suatu perjanjian jual beli tanah belum diatur didalam undangundang, sehingga seringkali terjadi wanprestasi, dengan adanya wanprestasi tersebut maka akibat hukum yang timbul adalah perjanjian yang dibuat oleh para pihak dapat dibatalkan atau batal dengan sendirinya.

Dan apabila akta jual beli tersebut sudah ditandatangani oleh Pejabat Pembuat Akta Tanah (PPAT), maka atas BPHTB yang telah dibayar tersebut tidak dapat diminta kembali sesuai dengan ketentuan pasal 9 ayat (1) huruf a Undang Undang Nomor 21 Tahun 1997 tentang Bea Perolehan Hak Atas Tanah dan Bangunan (BHTB).
\end{abstract}

Kata Kunci :Perlindungan hukum,Wanprestasi, Ikatan Jual Beli.

A. PENDAHULUAN

Latar Belakang Masalah

Perjanjian Pengikat Jual

Beli merupakan implementasi

Asas Kebebasan Berkontrak di

mana para pihak dapat

menentukan secara bebas

keinginannya lalu dituangkan

dalam klausula perjanjian.
Dalam perkembangannya asas ini dapat mendatangkan ketidakadilan karena prinsip ini hanya mencapai tujuannya yaitu mendatangkan kesejahteraan seoptimal mungkin, bila para pihak memiliki bargaining power yang seimbang. Dalam kenyataannya hal tersebut sering terjadi demikian sehingga negara 
menganggap perlu untuk campur tangan untuk melindungi para pihak yang lemah yang dituangkan dalam peraturan perundang-undangan dan campur tangan pengadilan melalui putusan-putusannya.

Perjanjian Pengikat Jual Beli adalah akta otentik yang dibuat di hadapan Notaris. Teori kontrak yang modern cenderung untuk menghapuskan syaratsyarat formal bagi kepastian hukum (Jack Beatson dan Daniel Friedman) sehingga perlu adanya pengaturan hukum yang tegas dalam menangani hal ini.

Negara yang menganut sistem common law, seperti di Amerika Serikat yang menerapkan doktrin promissory estoppels untuk memberikan perlindungan hukum kepada pihak yang dirugikan karena percaya dan menaruh pengharapan (reasonably relied) terhadap janji janji yang diberikan lawannya.

\section{B. METODE PENELITIAN Tipe Penelitian}

Dalam penelitian ini menggunakan jenis penelitian hukum normatif yaitu penelitian hukum yang dilakukan dengan cara meneliti bahan pustaka atau data sekunder, dan bahan hukum tersier. Bahan-bahan hukum tersebut disusun secara sistematis, dikaji kemudian ditarik suatu kesimpulan dalam hubungannya yang diteliti.

Penelitian Normatif digunakan untuk menemukan hukum bagi suatu perkara in concreto yaitu suatu usaha untuk menemukan apakah hukumnya sesuai untuk diterapkan dan digunakan untuk menyelesaikan suatu perkara.

\section{HASIL PENELITIAN DAN PEMBAHASAN \\ Perlindungan Hukum Bagi \\ Pihak Penjual Terhadap \\ Pihak Pembeli Wanprestasi \\ Dalam Ikatan Jual Beli \\ Tanah}

Perlindungan hukum dalam arti sempit adalah sesuatu yang diberikan kepada subjek hukum dalam bentuk perangkat hukum, baik yang bersifat preventif maupun represif, serta dalam bentuk yang tertulis maupun tidak tertulis. Dengan kata lain, perlindungan hukum dapat diartikan sebagai suatu gambaran dari fungsi hukum, yaitu ketentraman bagi segala kepentingan manusia yang ada di dalam masyarakat sehingga tercipta keselarasan dan keseimbangan hidup masyarakat.

Sedangkan perlindungan hukum dalam arti luas adalah tidak hanya diberikan kepada seluruh makhluk hidup maupun segala ciptaan Tuhan dan dimanfaatkan bersama-sama dalam rangka kehidupan yang adil dan damai.

Perlindungan hukum terhadap pemenuhan hak-hak para pihak apabila salah satu pihak melakukan wanprestasi dalam perjanjian pengikatan jual beli, maka tergantung kepada kedudukan dari perjanjian pengikatan jual beli dan wanprestasi.

Wanprestasi atau ingkar janji atau tidak memenuhi perikatan ada 3 (tiga) yaitu:

1. Debitur tidak sama sekali memenuhi perikatan; 
2. Debitur terlambat memenuhi perikatan;

3. Debitur keliru atau tidak pantas memenuhi perikatan;

Berdasarkan keterangan diatas terlihat bahwa ingkar janji bisa terjadi dalam beberapa bentuksebagaimana dikemukakan diatas.

Hal yang sama juga dapat terjadi dalam perjanjian pengikatan jual beli terhadap hak atas tanah. Karena tidak selamanya setiap orang yang membuat kesepakatan mampu untuk melaksanakan semua kesepakatan tersebut.

Dari keterangan diatas tergambar bahwa perlindungan hukum yang diberikan dalam perjanjian pengikatan jual beli sangat kuat karena sifat pembuktian dari perjanjian pengikatan jual beli yang dibuat dihadapan Notaris mempunyai pembuktian yang sangat kuat sesuai dengan pembuktian dari akta otentik.

Selain itu perlindungan lain yang diberikan adalah perlindungan hukum yang dibuat berdasarkan dari kesepakatan yang dibuat oleh para pihak yang terkait dengan perjanjian pengikatan jual beli yang jika kita kaitkan dengan peraturan tentang perjanjian, diatur dalam pasal 1338 Kitab Undang-Undang Hukum Perdata yang berbunyi : semua persetujuan yang dibuat secara sah berlaku sebagai undang-undang bagi mereka yang membuatnya.

Selain itu ada beberapa perlindungan yang dapat diberikan jika salah satu pihak melakuakn wanprestasi dal perjanjian pengikatan jual beli :
1) Perlindungan terhadap calon penjual

Perlindungan hukum yang dapat diberikan kepada calon penjual biasanya adalah berupa persyaratan yang biasanya dimintakan sendiri oleh calon penjual itu sendiri.

Misalnya ada beberapa calon penjual yang didalam perjanjian pengikatan jual beli yang dibuatnya memintakan kepada pihak pembeli agar melakukan pembayaran uang pembeli dengan jangka waktu tertentu yang disertai dengan syarat batal, misalnya apabila pembeli tidak memenuhi pembayaran sebagaimana telah dimintakan dan disepakati maka perjanjian pengikatan jual beli hak atas tanah yang telah dibuat dan disepakati menjadi batal dan biasanya pihak penjual tidak akan mengembalikan uang yang telah dibayarkan kecuali pihak pembeli meminta pengecualian.

2) Perlindungan terhadap calon pembeli

Berbeda dengan perlindungan terhadap penjual perlindungan terhadap pembelian biasanya selain dilakukan dengan persyaratan juga di ikuti dengan permintaan pemberian kuasa yang tidak dapat ditarik kembali. Tujuannya adalah apabila pihak penjual tidak memenuhinya maka pihak pembeli dapat menuntut dan memintakan ganti rugi sesuai dengan kesepaktan yang 
diatur dalam perjanjian pengikatan jual beli.

Persyaratan yang biasanya dimintakan oleh pembeli untuk perlindungannya adalah dengan memintakan supaya sertipikat atau tanda hak milik atas tanah tersebut dipegang oleh pihak ketiga yang biasanya adalah Notaris atau pihak lain yang ditunjuk dan disepakati bersama oleh penjual dan pembeli.

Selain itu perlindungan lain adalah dengan perjanjian pemberian kuasa yang tidak dapat ditarik kembali apabila semua persyaratan telah terpenuhi untuk melakukan jual beli, maka pihak pembeli dapat melakukan pemindahan hak walaupun pihak penjual tidak hadir dalam penandatangan akta jual belinya.

Berdasarkan semua keterangan diatas terlihat bahwa perlindungan hukum yang diberikan terhadap pemenuhan hak semua pihak dalam pengikatan jual beli, selain sesuai perlindungan hukum yang diberikan.

\section{Apa Akibat Hukum Yang Terjadi Ketika Pihak Pembeli Wanprestasi}

Wanprestasi ia alpa atau lalai atau ingkar janji. Atau juga ia melanggar perjanjian, bila ia melakukan atau berbuat sesuatu yang tidak boleh dilakukannya.

Ingka janji membawa akibat yang merugikan bagi debitur, karena sejak saat tersebut debitur berkewajiban mengganti kerugian yang timbul sebagai akibat dari pada ingkar janji tersebut.

$\begin{array}{ccr} & \text { Akibat hukum bagi pembeli } \\ \text { yang telah melakukan }\end{array}$

wanprestasi adalah hukuman atau sanksi berikut ini :

1. Pembeli diharuskan membayar ganti kerugian yang telah diderita oleh penjual (pasal 1243 Kitab Undang-Undang Hukum Perdata). Ketentuan ini berlaku untuk semua perikatan.

2. Dalam perjanjian timbal balik (bilateral), wanprestasi dari satu pihak memberikan hak kepada pihak lainnya membatalkan atau memutuskan perjanjian lewat hakim (pasal 1266 Kitab Undang-Undang Hukum Perdata).

3. Resiko beralih kepada pembeli sejak saat terjadinya wanprestasi (pasal 1237 Kitab Undang-Undang Hukum Perdata). Ketentuan ini hanya berlaku bagi perikatan untuk memberikan sesuatu.

4. Membayar biaya perkara apabila diperkarakan dimuka hakim pasal 181 ayat 1 (HIR) Herziene Inland Reglement. Pembeli yang terbukti melakukan wanprestasi tentu dikalahkan dalam perkara. Ketentuan ini berlaku untuk semua perikatan.

5. Memenuhi perjanjian jika masih dapat dilakukan, atau pembatalan perjanjian disertai dengan pembayaran ganti kerugian (pasal 1267 Kitab Undang-Undang Hukum Perdata). Ini berlaku untuk semua perikatan.

Mengenai pembatalan perjanjian atau juga dinamakan pemecahan perjanjian, sebagai sanksi kedua atas kelalaian seorang debitur, mungkin ada 
orang yang tidak dapat melihat sifat pembatalannya atau pemecahan tersebut sebagai suatu hukuman.

Pembatalan perjanjian, bertujuan membawa kedua belah pihak kembali pada keadaan sebelum perjanjian diadakan. Kalau suatu pihak sudah menerima sesuatu dari pihak yang lain, baik uang maupun barang, maka itu harus dikembalikan. Pokoknya, perjanjian itu ditiadakan.

Masalah pembatalan perjanjian karena kelalaian atau wanprestasi piha debitur ini, dalam Kitab Undang-Undang Hukum Perdata terdapat pengaturannya pada pasal 1266 , yaitu suatu pasal yang terdapat dalam bagian kelima Bab I, Buku III, yang mengatur tentang perikatan bersyarat.

Perolehan hak atas tanah dan bangunan karena jual beli merupakan cara memperoleh hak yang paling banyak dilakukan oleh masyarakat. Pada jual beli perlakuan BPHTB adalah berlaku umum dan tidak memandang siap yang melakukan transaksi jual beli.

Dalam hal akta jual beli yang telah ditandatangani oleh Pejabat Pembuat Akta Tanah (PPAT) namun karena suatu hal, kedua belah pihak sepakat untuk membatalkan jual beli tersebut, maka atas BPHTB yang telah dibayar tersebut tidak dapat diminta kembali sesuai dengan ketentuan pasal 9 ayat (1) huruf a Undang Undang Nomor 21 Tahun 1997 tentang Bea Perolehan Hak Atas Tanah dan Bangunan (BHTB), karena saat terutang BPHTB adalah sejak dibuat dan ditandatanganinya akta jual beli oleh PPAT yang wajib dilunasi oleh pihak pembeli sebagai wajib pajak.

\section{PENUTUP}

\section{Kesimpulan}

Dari penjelasan yang dijabarkan oleh penulis tersebut diatas dapat ditarik beberapa kesimpulan, antara lain :

a) Perlindungan hukum yang dapat diberikan kepada penjual adalah berupa persyaratan yang biasanya dimintakan sendiri oleh calon penjual itu sendiri. Misalnya ada beberapa calon penjual yang didalam perjanjian pengikatan jual beli yang dibuatnya memintakan kepada pihak pembeli agar melakukan pembayaran uang pembeli dengan jangka waktu tertentu yang disertai dengan syarat batal, dan apabila pembeli tidak memenuhi pembayaran sebagaimana telah dimintakan dan disepakati maka perjanjian pengikatan jual beli hak atas tanah yang telah dibuat dan disepakati menjadi batal dan biasanya pihak penjual tidak akan mengembalikan uang yang telah dibayarkan kecuali pihak pembeli meminta pengecualian.

b) Wanprestasi terjadi apabila seorang (pembeli) lalai melaksanakan kewajibannya sebagaimana kesepakatan yang telah diatur dalm perjanjian pengikatan jual beli antara penjual dan pembeli. Dengan adanya wanprestasi tersebut, maka 
akibat hukum yang timbul adalah perjanjian yang dibuat oleh para pihak dapat dibatalkan atau batal dengan sendirinya. Dan atas BPHTB yang telah dibayar tersebut tidak dapat diminta kembali sesuai dengan ketentuan pasal 9 ayat (1) huruf a Undang Undang Nomor 21 Tahun 1997 tentang Bea Perolehan Hak Atas Tanah dan Bangunan. (Surat Direktur Jendral Pajak Nomor : $\quad$ S471/PJ.331/2000).

\section{Saran-Saran}

a) Seharusnya perlindungan hukum bagi para pihak dalam perjanjian jual beli diatur oleh undang-undang, sehingga sedikit kemungkinan antara para pihak tersebut tidak melaksanakan hak dan kewajibannya sebagai penjual dan pembeli.

b) Dalam melakuakan perjanjian seharusnya pihak pembeli melakukan hak dan kewajibannya sebagimana mestinya, sehingga dalam perjanjian tersebut tidak terjadi wanprestasi di dalamnya.

E. DAFTAR PUSTAKA

Soerjono Soekanto. 2008. Pengantar Penelitian

Hukum. Jakarta : UI Press.

Soesilo. 1985. RIB/HIR dengan Penjelasan. Bogor : Politea.

Subekti. 1979. Hukum Perjanjian. Jakarta: Intermasa.
Subekti. 1994. Pokok-Pokok Hukum Perdata. Jakarta: Intermasa.

R. Setiawan. 1997. PokokPokok Hukum Perikatan. Bandung : P.T. Bina Cipta.

R. Subekti dan R. Tjitrosudibio. 2004. Kitab Undang-Undang Hukum Perdata. Jakarta: PT. Pradnya Paramita.

PERUNDANG-

UNDANGAN:

Undang-Undang Dasar Negara Republik Indonesia Tahun 1945 pasca amandemen.

Undang Undang Nomor 21 Tahun 1997 tentang Bea Perolehan Hak Atas Tanah dan Bangunan 